\title{
The cellular infiltrate of the jejunum in adult coeliac disease and dermatitis herpetiformis following the reintroduction of dietary gluten
}

\author{
M. LANCASTER-SMITH, PARVEEN J. KUMAR, AND A. M. DAWSON \\ From the Department of Gastroenterology, St Bartholomew's Hospital, London
}

SUMMARY The cellular infiltrate of the jejunal mucosa has been studied in patients with both treated and untreated adult coeliac disease and dermatitis herpetiformis and serially in treated patients before and after the reintroduction of gluten to the diet. In adult coeliac disease and dermatitis herpetiformis the jejunal mucosa showed similar abnormalities of the cellular infiltrate which was characterized by an increase in intraepithelial lymphocytes and lamina propria plasma cells and eosinophils, with the greatest numbers of cells occurring in untreated patients.

At 24-48 hours following a single 25-g gluten challenge there was an increase in lamina propria plasma cells, lymphocytes and eosinophils and intraepithelial lymphocytes. This rise was sustained after seven days on a gluten-containing diet for all of these cell groups except lamina propria lymphocytes. These responses were essentially similar in both adult coeliac disease and in those dermatitis herpetiformis patients who had jejunal lesions before treatment. In dermatitis herpetiformis patients with normal jejunal morphology on a normal diet there was an upward trend in lamina propria plasma cells and intraepithelial lymphocytes within one to three weeks of taking extra dietary gluten. These results are compatible with the view that more than one immunological mechanism may be responsible for the pathogenesis of the jejunal lesion of coeliac disease and dermatitis herpetiformis.

Immunohistochemical (Douglas, Crabbé, and Hobbs, 1970; Pettingale, 1971; Savilahti, 1972; Shiner and Ballard, 1972; Doe, Henry, and Booth, 1974) and ultrastructural (Shiner, 1973) studies suggest that humoral immune reactions play a part in the pathogenesis of the jejunal lesion of coeliac disease. Other observations, however, suggest that cell-mediated mechanisms involving either thymusdependent (Ferguson, 1974) or non-immune lymphocytes (Ezeoke, Ferguson, Fakhri, Hekkens, and Hobbs, 1974) are important. This local immune activity is reflected in an excess of intraepithelial lymphocytes (Ferguson and Murray, 1971) and abnormal numbers of lamina propria cells in the jejunum (Ferguson, 1974; Montgomery and Shearer, 1974). However, the evolution of the changes in these cell populations following the reintroduction of gluten to previously treated patients has not been studied. Alterations in plasma cell and lymphocyte

Received for publication 17 June 1975. numbers might implicate humoral or cell-mediated mechanisms respectively, whilst an early increase in granulocytes would support existing evidence that immune complexes are involved (Shiner and Ballard, 1972; Doe et al, 1974). The aim of this study, therefore, was to obtain information about these particular cell classes in the hope of clarifying the processes involved in the pathogenesis of the small intestinal lesion of coeliac disease and the related condition of dermatitis herpetiformis in which a similar enteropathy occurs.

\section{Patients and Methods}

PATIENTS

The diagnosis of adult coeliac disease was made on clinical and biochemical evidence of malabsorption, villous atrophy of the jejunum and previous or subsequent reversal of these features on a gluten-free diet. Dermatitis herpetiformis was diagnosed on clinical and histological features of the rash and its response to Dapsone. 


\section{ADULT COELIAC DISEASE}

Eleven patients who had been on a gluten-free diet from one to 15 years (mean 4.3 years) were studied. Before the gluten challenge villous heights ranged from 193 to 410 microns (mean 315 microns, normal $>330$ microns) and surface cell heights from 21 to 34 microns (mean 28 microns, normal $>29$ microns). Biopsies from 12 patients with untreated adult coeliac disease with subtotal villous atrophy were also examined.

\section{DERMATITIS HERPETIFORMIS}

Twelve patients, nine of whom had a previous significant jejunal lesion, were studied. These nine had been on a gluten-free diet from five to 24 months (mean 16 months). Before gluten challenge villous heights ranged from 199 to 478 microns (mean 353 microns) and surface cell heights ranged from 28 to 33 microns (mean 30 microns). The three remaining patients had never been on a gluten-free diet and had normal jejunal morphology with villous heights from 483 to 517 microns and surface cell heights from 30 to 34 microns. Biopsies from eight untreated patients with dermatitis herpetiformis and severe jejunal lesions were also examined.

\section{CONTROLS}

Jejunal biopsies were obtained from eight patients who were undergoing investigations for gastrointestinal symptoms, all of whom had normal small bowel morphology.

\section{Methods}

Gluten challenges were of three types:

1 Fourteen patients (eight with adult coeliac disease and six with dermatitis herpetiformis) had jejunal biopsies while on gluten-free diets and again after seven days on a diet containing between 10 and $20 \mathrm{~g}$ of gluten per day in the form of normal dietary constituents.

2 Seven patients (four with adult coeliac disease and three with dermatitis herpetiformis) on gluten- free diets were biopsied before and at 24 to 48 hours following a single $25-\mathrm{g}$ dose of gluten.

3 The three dermatitis herpetiformis patients who had normal jejunal morphology on diets containing 10 to $20 \mathrm{~g}$ of gluten per day were biopsied again between one and three weeks after taking $40 \mathrm{~g}$ of extra gluten per day as a single measured amount of gluten.

Biopsies were taken in all instances by a Crosby capsule in fasting subjects from the duodeno-jejunal flexure. The tissue was processed conventionally and $5 \mu$ sections were stained with haematoxylin and eosin and methyl green pyronine and alcian blue. Lamina propria cells were counted at a magnification of 1000 over an area of $0.25 \mathrm{~mm}^{2}$ from representative zones between the muscularis mucosa and epithelium, results being expressed as cells per $\mathrm{mm}^{2}$ (Savilahti, 1972). A particular note was made of the numbers of plasma cells, lymphocytes, eosinophils and neutrophils. Intraepithelial lymphocytes were also counted, results being expressed as lymphocytes per 100 epithelial cells (Ferguson and Murray, 1971).

Paired and unpaired Student $t$ test and Wilcoxon's sum of ranks test were used for statistical analysis where appropriate.

\section{Results}

\section{LAMINA PROPRIA}

\section{Plasma cells}

Patients with adult coeliac disease and dermatitis herpetiformis on a normal diet had the same number of plasma cells, and in both these were much greater than controls $\left(P=6 \times 10^{-12} ; P=3 \times 10^{-6}\right)$. Adult coeliac and dermatitis herpetiformis patients on a gluten-free diet also had a similar number of plasma cells, which, although fewer than in patients on normal diets $\left(P=3 \times 10^{-6} ; P=0.0002\right)$, were greater than in controls $(P=0.0003, P<0.05)$ (table I). After seven days on a gluten-containing diet plasma cells increased compared with pregluten levels in both the patients with adult coeliac disease $(P=0.03)$ and those with dermatitis herpetiformis $(P=0.05)$

\begin{tabular}{|c|c|c|c|c|c|c|}
\hline & \multirow[t]{2}{*}{ Nos. } & \multicolumn{4}{|c|}{ Lamina Propria (cells per $\mathrm{mm}^{2}$ ) } & \multirow{2}{*}{$\begin{array}{l}\text { Epithelium } \\
\text { (Lymphocytes per } 100 \\
\text { (Epithelial Cells) }\end{array}$} \\
\hline & & Plasma Cells & Lymphocytes & Eosinophils & Neutrophils & \\
\hline $\begin{array}{l}\text { Treated coeliac disease } \\
\text { Untreated coeliac disease } \\
\text { Treated dermatitis herpetiformis } \\
\text { Untreated dermatitis herpetiformis } \\
\text { Controls }\end{array}$ & $\begin{array}{r}11 \\
12 \\
9 \\
8 \\
8\end{array}$ & $\begin{array}{l}3187 \pm 176 \\
5908 \pm 177 \\
2742 \pm 282 \\
6116 \pm 436 \\
2028 \pm 137\end{array}$ & $\begin{array}{l}1556 \pm 106 \\
1499 \pm 163 \\
1390 \pm 180 \\
1578 \pm 133 \\
1714 \pm 101\end{array}$ & $\begin{array}{l}284 \pm 25 \\
517 \pm 53 \\
191 \pm 46 \\
569 \pm 107 \\
240 \pm 35\end{array}$ & $\begin{aligned} 17 & \pm 6 \\
88 & \pm 21 \\
1 & \pm 1 \\
25 & \pm 13 \\
0 & \pm 0\end{aligned}$ & $\begin{array}{l}48 \pm 5 \\
67 \pm 5 \\
36 \pm 3 \\
58 \pm 5 \\
23 \pm 3\end{array}$ \\
\hline
\end{tabular}

Table I Cellular infiltrate of the jejunum in patients with adult coeliac disease and dermatitis herpetiformis 

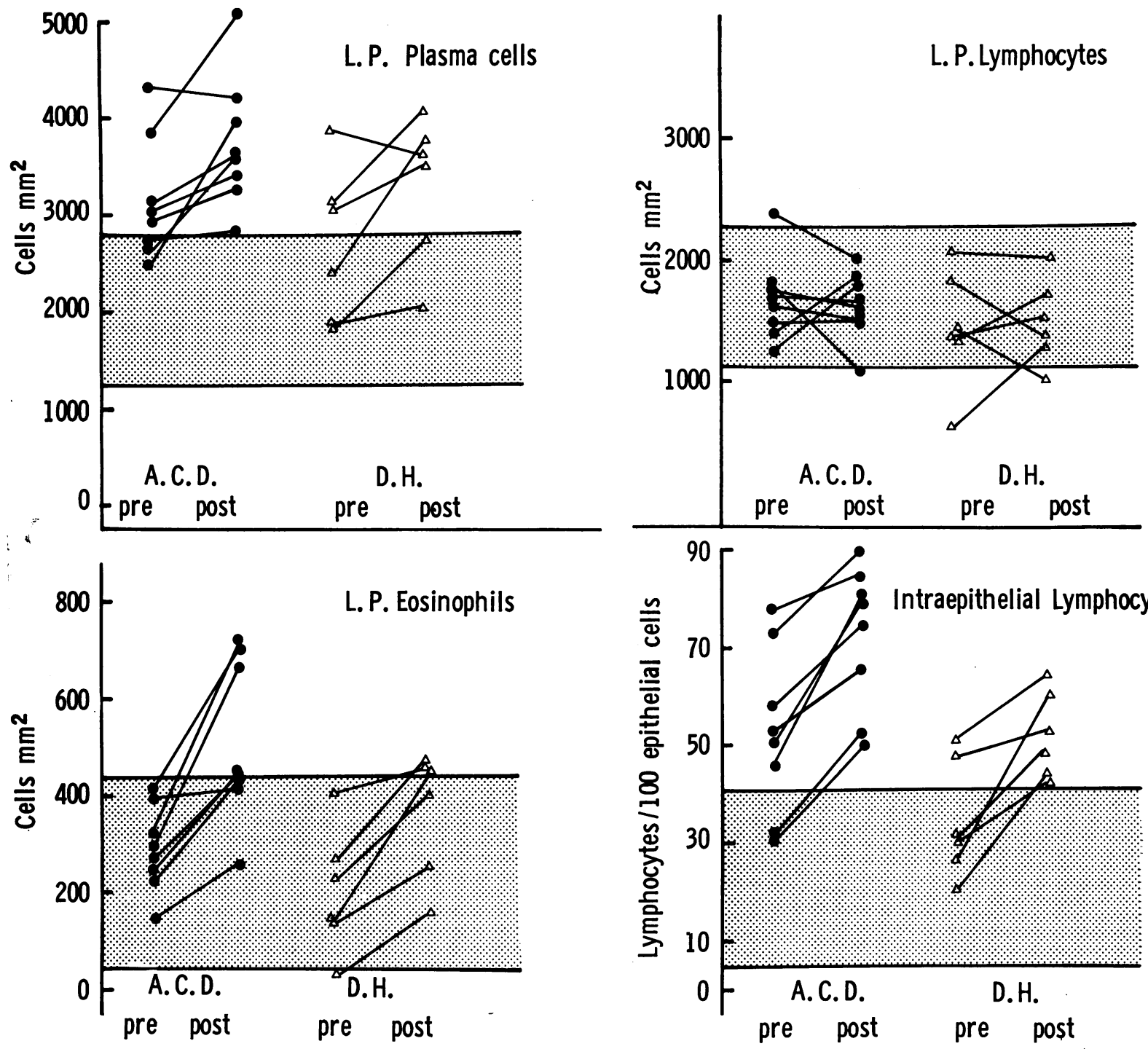

Fig 1

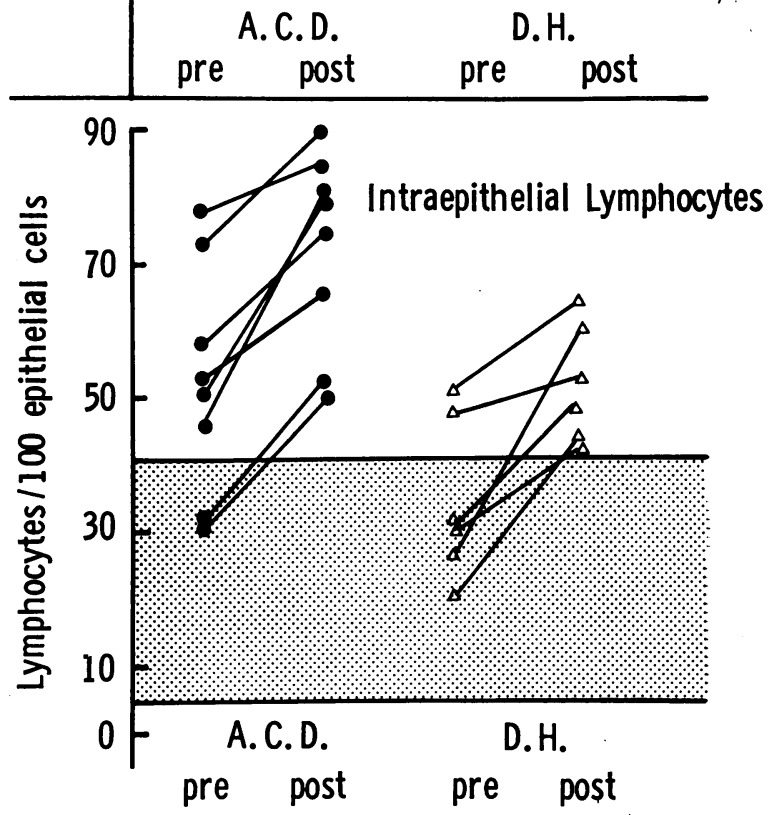

Fig 2

Figs 1 and 2 Lamina propria (LP) cells and intraepithelial lymphocytes in adult coeliac disease (ACD) and dermatitis herpetiformis $(D H)$ before and after a single 25-g gluten challenge.

(fig 1). In the patients studied at 24 to 48 hours after a single $25-\mathrm{g}$ gluten challenge there was also an increase compared with prechallenge levels $(P=$ 0.04) (fig 3).

\section{Lymphocytes}

There were the same numbers of lamina propria lymphocytes in both patients with adult coeliac disease and dermatitis herpetiformis and there was no difference between patients on gluten-free or normal diets. The number of lymphocytes in the patients tended to be slightly lower than in controls but the difference was not significant (table I). There was no change in counts after seven days on a glutencontaining diet compared with the preceding glutenfree diet levels (fig 2). In contrast, 24-48 hours after a single 25-g gluten challenge there was a detectable increase in cells compared with prechallenge levels $(\mathrm{P}<0.01)$, although numbers remained within the normal range (fig 3). 

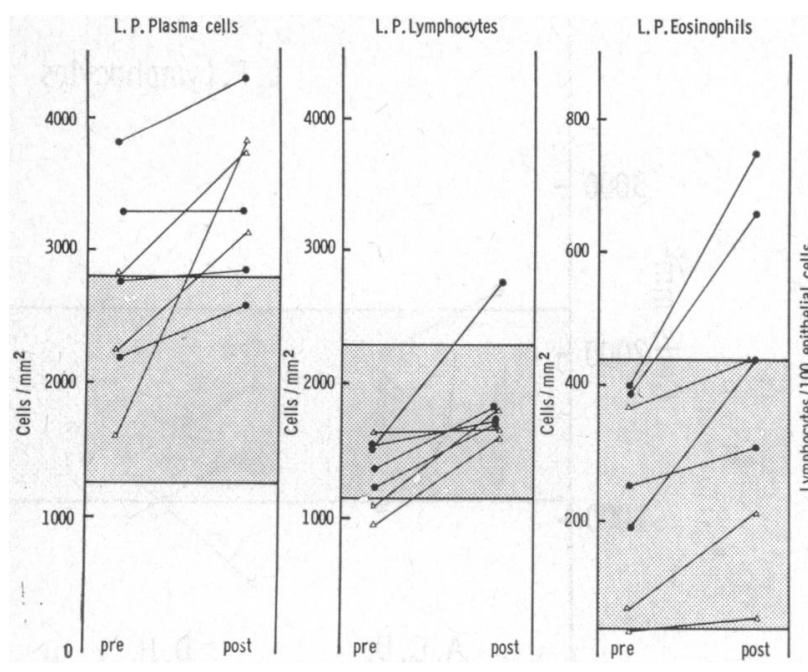

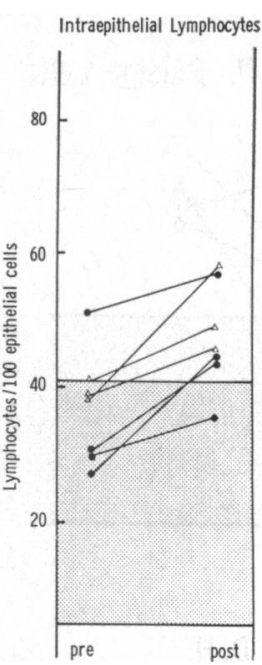

Fig 3 Lamina propria $(L P)$ cells and intraepithelial lymphocytes in adult coeliac disease $(A C D)$ and dermatitis herpetiformis $(\mathrm{DH})$ before and after seven days on 10-20g gluten per day.

Solid circles $=A C D$, open triangles $=\mathrm{DH}$, hatched areas $=$ control ranges.

\section{Eosinophils}

These were relatively sparse, tended to occur in clusters and varied in numbers from one field to another considerably more than either plasma cells or lymphocytes. They were more frequent in untreated patients with adult coeliac disease and dermatitis herpetiformis compared with treated patients $(\mathrm{P}<0.002, \mathrm{P}<0.002)$ and controls $(\mathrm{P}<$ $0.002, \mathrm{P}<0.002$ ), but in contrast to plasma cells there was no difference between treated patients and controls (table I). After seven days on a glutencontaining diet there was a rise in both adult coeliac disease $(P=0.002)$ and dermatitis herpetiformis $(P=0.003)$ (fig 1) and a similar increase was found at 24 to 48 hours after a single $25-\mathrm{g}$ gluten challenge ( $P=0.01$ ) (fig 3 ).

\section{Neutrophils}

These were not found in control biopsies and occurred in only very small numbers in both adult coeliac disease and dermatitis herpetiformis. When present they were usually in the vicinity of capillaries. Numbers varied widely from one biopsy to another, but in general the highest counts were found in those from untreated patients and following gluten challenge (tables I and II).

\section{INTRAEPITHELIAL LYMPHOCYTES}

Apart from small numbers of eosinophils these were the only non-epithelial cells found in the epithelial cell layer. Numbers were increased in untreated patients with adult coeliac disease and dermatitis herpetiformis compared with treated patients $(P<0.05, P<0.01)$ and controls $(P<$ $0.002, P<0.002)$. Treated adult coeliac disease and dermatitis herpetiformis patients also had greater numbers than controls $(\mathrm{P}<0.002, \mathrm{P}<0.01)$ (table I). After seven days on a gluten-containing diet intraepithelial lymphocytes increased compared with pregluten levels in both adult coeliac disease $(P=$ $0.002)$ and dermatitis herpetiformis $(P=0.007)$ (fig 2) and in the patients studied after a single $25-\mathrm{g}$ gluten challenge there was an increase at 24 to 48 hours $(P=0.002)$ (fig 3$)$.

The three untreated dermatitis herpetiformis patients without a jejunal lesion had normal numbers of cells in the lamina propria and epithelium when on normal diets but showed a slight increase in plasma

\begin{tabular}{|c|c|c|c|c|c|c|}
\hline & \multirow[t]{2}{*}{ Nos. } & \multicolumn{4}{|c|}{$\begin{array}{l}\text { Lamina Propria } \\
\text { (cells per } \mathrm{mm}^{2} \text { ) }\end{array}$} & \multirow{2}{*}{$\begin{array}{l}\text { Epithelium } \\
\text { (Lymphocytes per } \\
100 \text { (Epithelial Cells) }\end{array}$} \\
\hline & & Plasma Cells & Lymphocytes & Eosinophils & Neutrophils & \\
\hline $\begin{array}{l}\text { Before challenge } \\
\text { After challenge }\end{array}$ & $\begin{array}{l}3 \\
3\end{array}$ & $\begin{array}{l}2370 \pm 245 \\
3153 \pm 545\end{array}$ & $\begin{array}{l}1584 \pm 160 \\
1625 \pm 80\end{array}$ & $\begin{array}{l}259 \pm 73 \\
389 \pm 62\end{array}$ & $\begin{array}{r}3 \pm 3 \\
37 \pm 18\end{array}$ & $\begin{array}{l}34 \pm 3 \\
49 \pm 9\end{array}$ \\
\hline
\end{tabular}

Table II Cellular infiltrate of the jejunum in dermatitis herpetiformis patients with normal mucosa on a normal diet before and after extra gluten 
cells and intraepithelial lymphocytes while taking $40 \mathrm{~g}$ of extra gluten per day for one to three weeks. The numbers studied, however, were too small for statistical comparison (table II).

\section{Discussion}

The increase in jejunal plasma cells following gluten challenge in adult coeliac disease and dermatitis herpetiformis agrees with our previous studies using immunohistochemical techniques, which demonstrated under the same conditions an increase in immunoglobulin-containing cells, the majority of which were considered to be plasma cells (LancasterSmith, Kumar, Marks, Clark, and Dawson, 1974a). The greatly increased numbers of jejunal plasma cells in untreated adult coeliac and dermatitis herpetiformis patients when compared with normal, and the intermediate numbers in treated patients agree with previous studies in coeliac disease (Ferguson et al, 1974; Montgomery and Shearer, 1974). The absolute numbers of plasma cells in our coeliac patients are well within the range reported by Montgomery and Shearer (1974) but are lower than those found by Ferguson et al (1974). This may be for technical reasons such as the different methods of counting or to observer variation in the interpretation of cell types. It was our experience that large numbers of cells were difficult to identify with certainty and have not therefore been included in any of the cell categories. Alternatively there may have been real variations between patients in different studies, particularly in treated cases with regard to duration and strictness of the gluten-free diet. It seems likely that the $25 \%$ plasma cell increase within 24 to 48 hours of gluten challenge is an indication of the humoral-mediated immunological response to gluten per se. Whether the even greater excess of plasma cells in untreated patients is exclusively due to gluten is doubtful and it seems possible that much of this reaction is chronically stimulated by other antigens crossing the more severely damaged epithelium.

As in the patients of Montgomery and Shearer (1974), lamina propria lymphocytes tended to be fewer in patients than in controls whereas Ferguson et al (1974) demonstrated a significant reduction. The present finding that intraepithelial lymphocytes are increased in adult coeliac disease and dermatitis herpetiformis with the greatest numbers occurring in untreated patients confirms previous reports (Ferguson et al, 1971; Fry, Seah, McMinn, and Hoffbrand, 1972). Our observations on lymphocyte populations in both lamina propria and epithelium following gluten challenge would suggest that there is an increased flow of lymphocytes into the jejunal mucosa within 24 hours of ingestion of gluten. It is not known why an increase in lamina propria lymphocytes is no longer detectable after seven days' ingestion of gluten or why counts tend to be well below normal in some untreated coeliac patients (Ferguson et al, 1974). A possible explanation is that with prolonged exposure to gluten there is an increased migration of lymphocytes from the lamina propria into the epithelial cell layer, from which in untreated coeliac disease there may be an increased loss into the gut lumen (Weetman, Haggith, and Douglas, 1974). These changes in distribution might imply that lymphocyte-mediated immunological mechanisms play a part in the pathogenesis of the mucosal lesion. Alternatively the reduction in lamina propria lymphocytes and the increase in plasma cells might be due to transformation from one cell type to another.

By using quantitative methods we have substantiated the impression that eosinophils increase in the mucosa following gluten challenge (Shiner and Ballard, 1972). Our results in untreated patients agree with those of Pettingale (1971) who reported an increase in eosinophils, but are at variance with those of Montgomery and Shearer (1974) who found normal counts. The small numbers of neutrophils in the lamina propria following gluten challenge agrees with previous observations (Shiner and Ballard, 1972; Doe et al, 1974). Both eosinophil and neutrophil granulocytes are attracted by immune complexes (Kay, 1970). These findings might thus indirectly support the opinion that immune complexes are deposited in the jejunal mucosa during the early stages of the immunological reaction to gluten (Shiner and Ballard, 1972; Doe et al, 1974). Lymphocytes are also involved in eosinophilotaxis (Cohen and Ward, 1971) and it could be that this is reflected in the concomitant initial lymphocyte increase following challenge. It is therefore clear that many cell types are involved in the response following gluten ingestion. This is compatible with current knowledge and opinion (Lancet, 1974) that more than one immunological mechanism may be responsible for the jejunal lesion of coeliac disease.

Although coeliac disease and dermatitis herpetiformis are closely related disorders there are clinical and pathological differences. Thus the presence in dermatitis herpetiformis of cutaneous immunoglobulin and complement deposition (Seah, Fry, Mazaheri, Mowbray, Hoffbrand, and Holborow, 1973), the common association with atrophic gastritis (Fausa, 1974; Lancaster-Smith, Kumar, and Johnson, 1974b), and the increased incidence of autoantibodies against nuclei (Seah et al, 1971), thyroid (Fraser, 1970) and gastric parietal cells (Fraser, 1970; Lancaster-Smith et al, 1974b) suggests a more 
widespread disturbance of immunity than is found in the majority of patients with coeliac disease. In patients on normal quantities of dietary gluten there is usually a less severe jejunal inflammatory cell infiltrate and mucosal damage in dermatitis herpetiformis than in coeliac disease (Brow, Parker, Weinstein, and Rubin, 1971). Surprisingly, however, in dermatitis herpetiformis the inflammatory infiltrate following an identical large gluten challenge was comparable to that of coeliac disease although there was a less pronounced small bowel lesion assessed by villous derangement and surface cell heights. This suggests either that the small intestinal mucosa of dermatitis herpetiformis is more resistant to the effects of a gluten-induced inflammatory cell response or that the inflammatory infiltrate itself is not directly related to the pathogenesis of the epithelial cell lesion. Alternatively, it might be that any differences in the small intestinal reaction to gluten in the two diseases are too subtle to be detected by a simple study of the mucosal infiltrate.

\section{References}

Brow, J. R., Parker, F., Weinstein, W. M., and Rubin, C. E. (1971). The small intestinal mucosa in dermatitis herpetiformis. Gastroenterology, 60, 355-361.

Cohen, S., and Ward, P. A. (1971). In vitro and in vivo activity of a lymphocyte and immune complex-dependent chemotactic factor for eosinophils. J. exp. Med., 133, 133-146.

Doe, W. F., Henry, K., and Booth, C. C. (1974). Complement in coeliac disease. In Coeliac Disease: Proceedings of the 2nd International Coeliac Symposium, edited by W. T. J. M. Hekkens and A. S. Pena, pp. 189-196. Stenfert Kroese, Leiden.

Douglas, A. P., Crabbé, P. A., and Hobbs, J. R. (1970). Immunochemical studies of the serum, intestinal secretions, and intestinal mucosa in patients with adult coeliac disease and other forms of coeliac syndrome. Gastroenterology, 59, 414-425.

Ezeoke, A., Ferguson, N., Fakhri, O., Hekkens, T. J. M., and Hobbs, J. R. (1974). Antibodies in the sera of coeliac patients which can coopt $\mathrm{K}$ cells to attack gluten labelled targets. In $\mathrm{Co}$ eliac Disease: Proceedings of the 2nd International Coeliac
Symposium, edited by W. T. J. M. Hekkens and A. S. Pena, pp. 176-188. Stenfert Kroese, Leiden.

Fausa (1974). Reduction of gastric acid secretion and gastritis in dermatitis herpetiformis. In Coeliac Disease: Proceedings of the 2nd International Coeliac Symposium, edited by W. T. J. M. Hekkens and A. S. Pena, pp. 373. Stenfert Kroese, Leiden.

Ferguson, A. (1974). Lymphocytes in coeliac disease. In Coeliac Disease: Proceedingsof the 2nd International Coeliac Symposium, edited by W. T. J. H. Hekkens and A. S. Pena, pp. 265-276. Stenfert Kroese, Leiden.

Ferguson, A., and Murray, D. (1971). Quantitation of intraepithelial lymphocytes in human jejunum. Gut, 12, 988-994.

Ferguson, R., Asquith, P., and Cooke, W. T. (1974). The jejunal cellular infiltrate in coeliac disease complicated by lymphoma. Gut, 15, 458-461.

Fraser, N. G. (1970). Autoantibodies in dermatitis herpetiformis. Brit. J. Derm., 83, 609-613.

Fry, L., Seah, P. P., McMinn, R. M. H., and Hoffbrand, A. V. (1972). Lymphocytic infiltration of epithelium in diagnosis of gluten-sensitive enteropathy. Brit. med. J., 3, 371-374.

Kay, A. B. (1970). Studies on eosinophil leucocyte migration. Clin. exp. Immunol., 7, 723-737.

Lancaster-Smith, M., Kumar, P., Marks, R., Clark, M. L., and Dawson, A. M. (1974a). Jejunal mucosal immunoglobulincontaining cells and jejunal fluid immunoglobulins in adult coeliac disease and dermatitis herpetiformis. Gut, 15, 371-376.

Lancaster-Smith, M., Kumar, P. and Johnson, IG. (1974b). Atrophic gastritis and dermatitis herpetiformis. Lancet, 2, 777.

Lancet (1974). Editorial. The coeliac philosophy. Lancet, 2, 501-502.

Montgomery, R. D., and Shearer, A. C. I. (1974). The cell population of the upper jejunal mucosa in trophical sprue and postinfective malabsorption. Gut, 15, 387-391.

Pettingale, K. W. (1971). Immunoglobulin containing cells in the coeliac syndrome. Gut, 12, 291-296.

Savilahti, E. (1972). Intestinal immunoglobulins in children with coeliac disease. Gut, 13, 958-964.

Shiner, M., and Ballard, J. (1972). Antigen-antibody reactions in jejunal mucosa in childhood coeliac disease after gluten challenge. Lancet, 1, 1202-1205.

Shiner, M. (1973). Ultrastructural changes suggestive of immune reactions in the jejunal mucosa of coeliac children following gluten challenge. Gut, 14, 1-12.

Seah, P. P., Fry, L., Hoffbrand, A. V., and Holborow, E. J. (1971). Tissue antibodies in dermatitis herpetiformis and adult coeliac disease. Lancet, 1, 834-836.

Seah, P. P., Fry, L., Mazaheri, M. R., Mowbray, J. F., Hoffbrand, A. V., and Holborow, E. J. (1973). Alternate-pathway complement fixation by IgA in the skin in dermatitis herpetiformis. Lancet, 2, 175-177.

Weetman, A. P., Haggith, J., and Douglas, A. P. (1974). Enteric loss of lymphocytes in coeliac disease and Crohn's disease. (Abstr.) Gut, 15, 823. 